\title{
An Overview of Coronaviruses: In-Silico Approach to Decipher Anti-SARS-CoV-2 Natural Products
}

Patil Shivprasad Suresh ${ }^{\delta}$, Shiv Shankar Gupta ${ }^{\delta}$, Anmol, Upendra Sharma*

Chemical Technology Division and AcSIR, CSIR-Institute of Himalayan Bioresource Technology, Palampur, Himachal Pradesh, 176061, India.

*Corresponding authors: Dr. Upendra Sharma, Chemical Technology Division, CSIR-IHBT, Palampur, India 176061

Email: upendraihbt@gmail.com;_upendra@ihbt.res.in,

${ }^{\delta}$ Equal contribution 


\section{Abstract}

In current study, we have focused on the outline of different coronaviruses including COVID19, along with potential therapeutic targets of SARC-CoV-2. Moreover, experimentally evident anti-coronavirus natural molecules were subjected for in silico screening against $\mathbf{M}^{\text {pro }}$ and RdRp of COVID-19, in order to predict effective cure agent for same. The chemical structures of all selected molecules and standard ligands were drawn by ChemDraw for molecular docking and pharmacokinetic analysis. All ligands were prepared using OPLS_2005 force field of LigPrep tool, Schrodinger suite 2017-4 keeping default setting for generation of ionization and tautomeric state as well as low energy 3D-conformer. The template of main protease (6LU7) and RdRp (7BV2), were retrieved from the RCSB-PDB database. Both protein's structure was pre-processed, and minimized by utilizing default setting as integrated into the software package Maestro, Schrodinger. Receptor grid was generated by specifying around centroid of internal merged ligand atom i.e. $\mathrm{N} 3$ in case of $\mathrm{M}^{\text {pro }}$, while best suited docking site was used in case of RdRp protein, predicted by Sitemap analysis tool, Schrodinger package. Molecular docking of selected bioactive natural products against target proteins was performed by using Glide module of Schrodinger package. Few water and avoidable molecules were removed, which amalgamated with docking site of the proteins template. The extra-precision (XP) and flexible molecular docking algorithm were employed to investigate free binding energy. In silico pharmacokinetic parameter was calculated with QikProp module of Schrodinger was utilized to predict in silico pharmacokinetic parameter of top ranked natural molecules. Docking analysis have revealed hit molecules namely tetra- $O$ galloyl- $\beta$-D-glucose (2) and juglanin (25) against main protease, in reference of N3 molecule $($ docking score $=-5.95 \mathrm{Kcal} / \mathrm{mol})$, while glycyrrhizin $(\mathbf{1})$ and tetra- $O$-galloyl- $\beta$-D-glucose (2) are good against RdRp in reference of Remdesivir (docking score $=-4.23 \mathrm{Kcal} / \mathrm{mol}$ ). In-silico parameter revealed three lead compounds i.e. glycyrrhizin (1), tetra- $O$-galloyl- $\beta$-D-glucose 
(2) and juglanin (25) which can be seen as hopeful molecule for COVID-19 treatment in upcoming time. Overall review lesson is to develop a specific and effective drug molecule against the current crisis i.e. COVID-19 derived from natural source.

Keywords: Coronavirus, SARS-CoV-2, COVID-19, Natural products, In-silico screening. 


\section{Introduction}

In December 2019, a modern city Wuhan, Hubei province of China, which have recorded several novel pneumonia cases, caused by novel coronavirus-infected pneumonia (NCIP) [1]. Wuhan is the central point of a pandemic upsurge of SARS-CoV-2 also referred to as HCoV19 [2] causative agent of COVID-19 which subsequently expanded [3] and it has caught global attention again after SARS-CoV in 2003 and the Middle East respiratory syndromerelated coronavirus (MERS-CoV), in 2012 outbreak. It is the deadliest coronavirus infection ever recorded with a mortality rate of $4-5 \%$ and a very high rate of transmission [4]. The coronavirus was originated more than 55 million years ago which was co-evolved with bats, and its most recent common ancestor (MRCA) has been estimated to have existed as recently as 8000 BCE [5]. The evolution of MRCA's of the different genera of Coronaviridae family such as the $\alpha$-coronavirus (2400 BCE), the $\beta$-coronavirus (3300 BCE), the $\gamma$-coronavirus (2800 BCE), and the $\delta$-coronavirus (3000 BCE) has been estimated [5]. The ideal hosts for the evolution and transmission of coronaviruses are that bats ( $\alpha$-coronavirus and $\beta$ coronavirus) and birds ( $\gamma$-coronavirus and $\delta$-coronavirus) [6]. The infectious bronchitis virus (IBV) was the first coronaviruses reported in the 1930s in chickens[7], while the first human coronaviruses were reported in the 1960s [8]. After that numerous human coronaviruses have been reported, including SARS-CoV (2003), HCoV NL63 (2004), HKU1 (2005), MERSCoV (2012), and SARS-CoV-2 (2019). History indicated that coronavirus outbreaks have a severe impact on human health. SARS-CoV (2002-2004) had infected 8,096 people in China, with a 9.2\% fatality rate [9]. MERS-CoV (2012) has infected 2494 people in Saudi Arabia, with a $37 \%$ fatality rate [10]. Currently, SARS-CoV-2 (2019-2020) had infected more than 19 million people globally with a $3.8 \%$ fatality [11]. A SARS-CoV-2 infection has been declared as a pandemic by the WHO on the 12th of March 2020. It was the seventh 
human coronavirus strain identified, which is associated with a severe respiratory infection like SARS-CoV and MERS-CoV, whereas NL63, HKU1, 229E, and OC43 have associated with mild sign [12]. The majority of the coronaviruses are responsible for extensive respiratory and gastrointestinal tract infections in humans and other animals [13][14].

Coronaviruses have stable and lasting threats for human health therefore we necessitate understanding their virology for controlling the transmission of coronavirus to stabilize public health and global economies. Due to the environment-dependent adaptability of coronaviruses through mutations and recombination, it provides them wide host range and tissue tropism [15][16][17]. Due to novelty of SARS-CoV-2 virus, there is lack of concrete data on the SARS-CoV-2 origin and COVID-19 treatments. The complete development of novel antiviral drugs for treating COVID-19 could be protracted, and the main concern could be a bio-safety. Therfore, it seems idealistic to investigate clinically tested molecules within a restricted time when the infection is spreading in exponential manner. Animals depend on their innate and adaptive immune system in order to defend against pathogenic microbes. Similarly, bacteria, algae, fungi, and plants, synthesize a variety of secondary metabolites for their defense mechanism. These natural products often target common biochemical pathways and cellular regulatory systems, which can be hijacked by viruses for their proliferation [18]. Therefore, natural products can be a potent arsenal of broad-spectrum antiviral agents. Why natural products? Because they are the outcome of million years of evolution, biologically compatible, and exhibited diverse stereochemistry which remains unrelated to existing drugs skeleton. Structural diversity is a fundamental prerequisite to hits a wide-range of therapeutic targets thus, natural products are considered as broad-spectrum agents for the defense purpose [19]. Traditional Chinese and Indian Ayurveda Medicine System have been utilized for thousands of years. Experimental evidence suggested that several natural products have acted as anti-SARS-CoV agents including, Glycyrrhizin (licorice/Glycyrrhiza glabra), 
lycorine (Lycoris radiate), and Ginsenoside-Rb1 (Panax ginseng) [20][21]. Numerous scientific investigations were confirmed honey has been as an effective antimicrobial natural formulation which could be considered an excellent alternative or combination for antiviral drugs [22].

Some questions are arising due to the current scenario like, why it's so lethal as compared to the other coronaviruses? Is it any structural or genetic evolutions which improved their mode of action, sustainability, and resistibility to the host? Is there any scope of natural products for the development of broad-spectrum antiviral drugs? In order to answer these questions, here we have reviewed the biochemistry, pathogenesis of coronavirus and antiviral medicinal plants, and natural products as cure agent. Intentionally, we have directed our attention on the identification of the anti-SARS-CoV-2 agents through docking study of experimentally evident natural products against SARS-CoV, which may act as foundation for the discovery of natural products based drugs.

\section{Coronavirus}

Coronaviruses are a group of (+) ssRNA enveloped viruses [23] that cause respiratory or gastrointestinal infection in birds and mammals. In humans, it has showed mild symptoms such as common cold, similar to rhinoviruses infections in some cases, while in other cases such as SARS, MERS, and COVID-19, it can be lethal. Coronaviruses categorized under family Coronaviridae, which meaning "crown" or "halo", which refers to the distinctive appearances of virions resembling solar corona under an electron microscope, due to the surface embedded glycoprotein spike peplomers [24].

\subsection{Morphology and genome}

Coronaviruses are the largest RNA viruses with the pleomorphic spherical form with projecting homotrimeric spike-proteins (peplomers) surrounded by envelope proteins [25]. 
Envelop protein has implicated the maturation and discharge of viruses, results in the progression of the infection. The diameter of the coronaviruses is ranging around from 120$160 \mathrm{~nm}$ [26]. The viral envelope developed by a lipid bilayer where the trimeric spike proteins are anchored which interacts with host receptors to enable the virus entery [27]. $\beta$ coronavirus has a 5-10-nm long shorter projection of peplomers called hemagglutinin esterase (HE) [28]. Inside the core of transmembrane proteins, which hold nucleocapsid associated with ss-RNA in a curvature arrangement [29]. Peripheral lipid bilayer, envelop, matrix proteins, and nucleo-proteins protect the genome when the virus is exterior the host cell (Fig. 1) [30].

The genome size of coronaviruses is approximately $27-34 \mathrm{~kb}$ [23] which has protected $3^{\prime}$ by polyadenylation and a $5^{\prime}$ by methylation [26]. Genome organization of SARS-CoV-2 as 5' UTR-[methylation]-(replicase/transcriptase)-(spike)-(envelope protein)-(matrix protein)(nucleocapsid)-3' UTR-[poly (A)] which is slightly different in different strains of coronaviruses [26]. There are two open reading frames (ORF) in coronaviruses such as ORF1a and ORF1b, that covered the first $2 / 3$ portion of the genome. ORF is highly conserved and encoded 16 non-structural proteins (nsp1-nsp16) [26], including nsp1 which facilitate host cellular mRNA lysis and obstruct translation, consequently, impede innate immune response [31][32][33], nsp13 is the RNA helicase and 5' triphosphatase [34] [35], and nsp15 is endoribonuclease and NendoU [36] [37]. The structural genes are common to all coronaviruses, while accessory genes are unique in number, organization, sequence, and function that encoded by specific coronaviruses. The translated product of the spike gene is cleaved after synthesis into the $\mathrm{N}^{\prime}$ subunit is $\mathrm{S} 1$, which interacts with host cell receptor; and the $C^{\prime}$ subunit is S2 subunit, which facilitate membrane fusion [38][39]. The genome SARSCoV-2 has shown $87.99 \%$ sequence identity with bat-SL-CoVZC45, 87.23\% with bat-SLCoVZXC21, and 79\% with SARS-CoV [40]. SARS-CoV-2 has classified into two types 
based on population genetic analysis, such as L-type $(\sim 70 \%)$ and S-type $(\sim 30 \%)$. The L-type strains are more aggressive and infectious, which are evolutionarily developed from S-type strains [41].

\subsection{Mode of Action and Pathogenesis}

Coronavirus entere into the host cell by the interaction between spike-glycoprotein and its complementary receptor. The S1 region of spike glycoprotein position of receptor binding domains (RBD) is varied in different viruses, either at the N-terminus (MHV) or at the Cterminus (SARS- CoV) [42][43]. The binding between the spike-glycoprotein and host receptor is the prime requisite for an infection and the tissue tropism of the coronaviruses. Mostly peptidases have utilized as host entry gate by coronaviruses. Several $\alpha$-coronaviruses interact with aminopeptidase N (APN) [44][45][46][47], while HCoV-NL63 and SARS-CoV interact with angiotensin-converting enzyme 2 (ACE-2) [48] [49], MERS-CoV utilize dipeptidyl-peptidase 4 (DPP4) [50], and MHV interact with CEACAM1 [51] [52]. Following virus-host interaction, spike glycoprotein has depredated by acid-dependent proteolysis by the host cell proteases, to promotes fusion of viral and host cell membranes. Generally, viruses fuse intracellularly with acidic endosomes, but few viruses like MHV, can fuse with host cell plasma membrane. Due to the cleavage of spike-glycoprotein, which results exposure to a fusion peptide that penetrates the membrane and endorse the formation of the antiparallel Hexa-helix bundle [53]. This Hexa-helix bundle allows for the viral and host membranes amalgamation, which leads to ejection of the viral genome into the host cells. The cluster of non-structural proteins (nsp's) forms a replicase-transcriptase complex including RNA-dependent RNA polymerase (RdRp) which involved in replication and transcription of RNA by catalyzing the synthesis of (-)-RNA from the (+)-RNA, while other nsp's are responsible for assisting this process [26]. The exoribonuclease provides additional fidelity to 
the replication by its proof reading activity which is lack in RdRp enzyme [26]. Membrane or $\mathrm{M}$ protein execute the assembly of viruses by protein-protein interactions followed by its coupling with the nucleocapsid and viral genome, which leads to release of virions by exocytosis from the host cell (Figure 1) [26].

Coronaviruses cause a severe upper respiratory and gastrointestinal tract infection in mammals and birds including livestock; therefore, it can be a serious threat to the farming industry. Coronavirus target the respiratory and urogenital tract in IBV infection, but it also spreads throughout the body of chicken [54]. Porcine and bovine coronavirus causes diarrhea in young animals and both are considered as economically significant viruses. Feline enteric coronavirus showed minor clinical symptoms, but the mutated form of the same virus is responsible for feline infectious peritonitis (FIP), which causes a high fatality. Similarly, ferret enteric coronavirus infects a ferret that causes epizootic catarrhal enteritis (ECE), which is gastrointestinal and deadlier one [55]. Canine coronavirus (CCoV) has also two forms, first one is mild form which causes gastrointestinal symptoms while other is severe form which causes respiratory symptoms. Coronaviruses in rodents is mouse hepatitis virus (MHV) is responsible for a worldwide murine contagion with a high fatality, particularly in laboratory mice [56]. Pigs are also the target of swine acute diarrhoea syndrome coronavirus (SARS-CoV) which shows symptoms like diarrhea [57].

Previous outbreaks of coronavirus like as SARS-CoV and MERS-CoV which is biological agents that threaten human health. In the case of SARS-CoV infection, the physiological symptoms appear after 5.2 days which is incubation period [3]. In SARS-CoV-2 infection, the period from the beginning of symptoms to death is approximately 1-6 weeks' days with a 14 days median [58]. Moreover, this fatality period is also dependent on the age, status of ongoing health issues, and immune system. If infected patients are $>70$ years old, those are on higher risk for fatality [58]. The symptoms of COVID-19 are cough with fever (body 
temperature of $39.0{ }^{\circ} \mathrm{C}$ ), difficulties in breathing fatigue, headache, diarrhea, sputum formation, haemoptysis, and lymphopenia (Figure 1) [59] [60].

COVID-19 patients generally have high leucocytes count with elevated levels of proinflammatory cytokines and chemokines including IL1- $\beta$, IL1RA, IL2 IL7, IL8, IL9, IL10, IFN $\gamma$, basic FGF2, GCSF, GMCSF, IP10, MCP1, MIP1 $\alpha, \operatorname{MIP} 1 \beta$, PDGFB, TNF $\alpha$, and VEGFA [59]. The sputum sample has taken for confirmation of COVID-19 infection by realtime polymerase chain reaction [61]. Moreover, the C-reactive protein level in blood is around $16.16 \mathrm{mg} / \mathrm{L}$ which is higher than the basal range $(0-10 \mathrm{mg} / \mathrm{L})$ [61]. The important pathophysiogenesis of COVID-19 are severe pneumonia, acute cardiac injury, RNAaemia [59]. SARS-CoV-2 accesses host lung cells via transmembrane ACE2 receptor which is highly expressed in type II alveolar cells of the lungs, therefore lungs are most distress organ by COVID-19 [62]. Together with lungs, a gastrointestinal tract also targeted by SARS-CoV2 due to abundant expression of ACE2 is in the enterocytes, glandular cells, and endothelial cells of the gastrointestinal tract [63][64].

\subsection{Challenges and Opportunity in COVID-19 Treatment}

The COVID-19 is a novel pneumonia-like severe disease, which is an unprecedented challenge and drastically affects global healths and the economy. Due to its novelty of this virus, there is lack of vaccine, effective anti-SARS-CoV-2 drug, therefore, we confront several challenges for the definitive treatment of COVID-19. Another important concern is the shortage of ICU facilities including isolation beds, ventilators, fluid management, and essential medicines like Hydroxychloroquine, which are also the barrier for treatments. Approximately $20.1 \%$ of COVID-19 patients were developed SARS, while $25.9 \%$ of patients required ICU facility for treatment [65]. 
The antiviral, anti-malarial, and herbal medicines have been alternative options for the treatment of COVID-19. Presently $>85 \%$ of COVID-19 patients have been treated by the anti-viral agents, including Oseltamivir, Lopinavir/Ritonavir, and Ganciclovir, while Remdesivir at present under clinical trials [65]. The critical condition of COVID-19 has been managed by the combination of corticosteroids and anti-viral agents along with atomized inhalation of IFN $\gamma$ [66]. The effective anti-malarial drug Chloroquine phosphate showed antiviral and anti-inflammatory potential, thereby it has been exploiting for the inhibiting the aggravated effects of pneumonia [67]. Some traditional Chinese herbal formulation was used for the treatment of SARS-COV infection, and also for COVID-19 management. The most effective anti-SARS-COV medicinal herbs, include Astragali radix (steroidal saponins and isoflavonoids), Glycyrrhizae radix Rhizome (flavonoids and triterpenoid saponins), Saposhnikoviae radix (chromones and coumarin), Atractylodis macrocephalae Rhizome (atractylon and atractylenolides), and Lonicerae japonicae (flavonoids, iridoid glycosides, and flavonoids), Forsythiae fructus (phenylethanoid glycosides, lignans) [68][69]. Convalescent plasma (immuno-globulins of recovered patients) has also been useful for selective and potential approach obliging for immediate and short-term treatment of COVID19 [70]. Earlier convalescent plasma therapy has been utilized for the recovery of the patients of H5N1, avian influenza, SARS, Ebola, and influenza A (H1N1 pdm09) infections [71][72].

\subsection{Potential therapeutic targets for COVID-19 treatment}

There are several potential targets in order to restrain coronavirus infection, which primarily associated with virus entry, viral genome replication, translation, assembly, and exocytosis [73]. Nsp's are functional proteins which are essential for executing the life cycle of coronaviruses. Among them, $\mathrm{RdRp}, \mathrm{PL}^{\text {pro }}, 3 \mathrm{CL}^{\text {pro }}$, and helicase are the key and most valid molecular targets for designing and development of an anti-coronaviral drug owing to their 
vital biological role. Viral proteases may prove as remarkable targets responsible for proteolysis of large polyprotein chain into different functional proteins such as replicase and polymerase [74]. For the development of an effective drugs against COVID-19, it is essential to hamper viral as well as host protein targets. The spike glycoprotein recognize the host cell receptor proteins ACE2 and CD147 as an alternative receptor, then spike protein proteolyzed by host proteases including transmembrane serine protease 2 (TMPRSS2) and furin [75][76]. Besides that, direct fusion of SARS-CoV-2 with the host cell membrane, it has also been postulated to penetrate through endocytosis [75]. In this pathway, some key proteins including, Vacuolar-type $\mathrm{H}^{+}$ATPase (V-ATPase), Cathepsin L (CTSL), two pore segment channel 2 (TPC2), and Phosphatidylinositol 3-phosphate 5-kinase (PIKfyve), which assist the formation of endosomes [75]. Above all mentioned viral and host proteins are considered as a probable target for the anti-coronaviral drugs and which are summarized in Table $\mathbf{1}$ with its natural inhibitors.

\section{Anti-coronaviral natural products}

Natural products always remain a crucial platform, in order to search a bioactive drug molecule, and play a vital role in the drug discovery process [77]. Medicinal plants have the potential for promising sources of novel antiviral prototypes [78]. Several compounds from extracts of diverse species of higher plants have shown antiviral activity such as tannins, flavones and alkaloids, which displayed in vitro activity against numerous viruses. Limited availability of currently available antiviral drugs is the driving force for the discovery of new antiviral agents. The primary approaches for the discovery of new herbal agent is the classical method involves random screening, phytochemical factors and serendipity approaches. The secondary approach is traditional knowledge and practices on ethnopharmacology, which may prove as one good choice for the discovery of antiviral agents, and it involves the study 
of medicinal plants with a history of traditional use as a potential source of substances with significant pharmacological activities [79] [80]. Herbal based therapeutic agent has several advantages too such as high effectiveness, less side effect, easy availability, and relatively low cost. Herein, we are more focused on compiling natural agents against SARS-CoV, which will anchor in the discovery of new antiviral agent especially against the current disaster started from Wuhan city of China.

At present, there is unavailablity of any potential existing or newly developed antiviral drug which can successfully treat COVID-19. Nevertheless, several research institutes are working on screening and clinical testing of potential antiviral small-molecules. The small molecules ligands can be categorized into two groups based on their therapeutic target - molecules of the first group are acting on the protein targets of coronaviruses, while molecules of the second group interact with host proteins to modulate the host immune system. In Table 2 we have compiled experimentally screened natural products against coronaviruses.

\section{Molecular docking screening \& pharmacokinetic study of natural inhibitor's}

The structures of all selected natural products (Fig. 2) were drawn by ChemDraw for molecular docking and ADME analysis against SARS-CoV-2 therapeutic targeted proteins. The stereochemical conformers of the natural products and standard ligands were prepared by using LigPrep tool, Schrodinger suite 2017-2, by utilizing OPLS_2005 force field. 3D template of main protease (PDB entry: 6LU7) \& RdRp (PDB entry: 7BV2), were retrieved from the RCSB-PDB database. Both selected protein's structure was pre-processed, optimized and minimized with the help of protein preparation wizard in Maestro software, Schrodinger by using default setting. We have generated receptor grid around the best suited docking site which was analysed by sitemap wizard, in case of RdRp protein (7BV2), while internal merged ligand i.e. N3 atom were selected in order to generate receptor grid in case of 
main protease (6LU7). Molecular docking of selected proteins with bioactive natural products was executed by using Glide, Schrodinger. Few water and avoidable molecules were removed, which amalgamated with docking site of the proteins template. The extra-precision (XP) algorithm with flexible molecular docking setting was employed to investigate binding affinity of ligands toward protein. Internal ligand i.e. N3 inhibitor [(Benzyl (3S,6S,9S,12R,Z)-9-isobutyl-6-isopropyl-3-methyl-1-(5-methylisoxazol-3-yl)-1,4,7,10-tetra oxo-12-(((R)-2-oxopyrrolidin-3-yl)methyl)-2,5,8,11-tetraazapentadec-13-en-15-oate)] in main protease crystal structure was utilized as reference ligand, whereas Remdesivir was used as reference in case of RdRp enzyme, in order to validate apex hit molecules against COVID-19. 
Docking analysis (Table. 3) has revealed hit molecules namely tetra- $O$-galloyl- $\beta$-D-glucose (2), \& juglanin (25) against protease, and same molecule i.e. tetra- $O$-galloyl- $\beta$-D-glucose (2) and glycyrrhizin against RNA replicase in reference of N3 inhibitor (docking score $=-5.95$ $\mathrm{Kcal} / \mathrm{mol}$ ) \& Remdesivir (docking score $=-4.23 \mathrm{Kcal} / \mathrm{mol}$ ). 3D-interaction diagram for apex hit molecules have shown in fig. 3. In silico pharmacokinetic parameters were calculated with QikProp module of Schrodinger suit. The pharmacokinetic profile study is one strong point to minimize drug failure rate during drug discovery process. Recommended pharmacokinetic parameter and their corresponding value is mentioned in below Table. 3 .

\section{Conclusion}

The pandemic contagion of the SARS-COV-2, their transmission rate and availability of no effective COVID-19 treatment is one of tough challenge for the medical and pharmaceutical fraternities. In an unprecedented display of effort and collaboration, the scientific community has made great strides in such a short amount of time which can be seen through publication of $>1,000$ SARS-CoV-2 genomes till now. Several crystal structures of key proteins of SARSCoV-2 have been solved now, including the spike glycoprotein, RNA replication machinery proteins, and viral proteases. The life cycle of SARS-CoV-2 is now reasonably well understood, owing to years of study on related coronaviruses. Here we have discussed what researchers have now learned about the viral infection pathway of COVID-19 with an emphasis on the emerging targets for new drugs and vaccines. We warmly believe that 'for every illness in the living organisms, somewhere in world there exist plants which are cure'. Hence, Nature makes available an easy way out for any complex difficulty. This encourages us to perform in-Silico screening of experimentally validated anti-coronaviral natural compounds to forecast the biocompatible inhibitors against coronavirus. In-silico parameter revealed three lead compounds i.e. tetra- $O$-galloyl- $\beta$-D-glucose (2), juglanin (25) \& glycyrrhizin (1) which can be seen as hopeful molecule for COVID-19 treatment in upcoming time. Therefore, our 
broad study from experimental to in silico stage, generates a high impact to produce safe natural therapeutics against current threat i.e. COVID-19.

\section{Funding}

The study is supported by CSIR (MLP0154/MLP 0159). SRF-fellowship to PSS and JRFfellowship to SSG is provided by CSIR Delhi, India.

\section{Author Contribution}

Patil Shivprasad Suresh and Shiv Shankar Gupta contributed to data collection, in silico screening, investigation, writing, designing, and editing of initial draft of manuscript. Anmol contributed to the investigation, data collection writing and editing of initial draft of manuscript. Upendra Sharma contributed to the conceptualization, Supervision, manuscript design and editing of manuscript.

\section{Acknowledgments}

We express our gratitude to the Director, CSIR-IHBT Palampur for his continuous support. We acknowledge CSIR-Delhi, for providing fellowship to PSS and SSG. CSIR manuscript number is 4625 .

\section{Conflicts of interest}

The authors declare no competing interests.

\section{References}

[1] Wu F, Zhao S, Yu B, Chen Y-M, Wang W, Song Z-G, et al. A new coronavirus associated with human respiratory disease in China. Nature 2020;579:265-9.

[2] Jiang S, Shi Z, Shu Y, Song J, Gao GF, Tan W, et al. A distinct name is needed for the new coronavirus. Lancet (London, England) 2020;395:949.

[3] Li Q, Guan X, Wu P, Wang X, Zhou L, Tong Y, et al. Early transmission dynamics in Wuhan, China, of novel coronavirus-infected pneumonia. N Engl J Med 2020. 
[4] Chen J. Pathogenicity and transmissibility of 2019-nCoV-a quick overview and comparison with other emerging viruses. Microbes Infect 2020.

[5] Wertheim JO, Chu DKW, Peiris JSM, Pond SLK, Poon LLM. A case for the ancient origin of coronaviruses. J Virol 2013;87:7039-45.

[6] Woo PCY, Lau SKP, Lam CSF, Lau CCY, Tsang AKL, Lau JHN, et al. Discovery of seven novel Mammalian and avian coronaviruses in the genus deltacoronavirus supports bat coronaviruses as the gene source of alphacoronavirus and betacoronavirus and avian coronaviruses as the gene source of gammacoronavirus and deltacoronavi. $\mathbf{J}$ Virol 2012;86:3995-4008.

[7] McIntosh K. Coronaviruses: a comparative review. Curr. Top. Microbiol. Immunol. der Mikrobiol. und Immunitätsforsch., Springer; 1974, p. 85-129.

[8] Tyrrell DAJ, Bynoe ML. Cultivation of viruses from a high proportion of patients with colds. Lancet 1966:76-7.

[9] Organization WH. Summary of probable SARS cases with onset of illness from 1 November 2002 to 31 July 2003. Http//Www Who Int/Csr/Sars/Country/Table2004_04_21/En/Index Html 2003.

[10] Middle East respiratory syndrome coronavirus (MERS-CoV). World Heal Organ 2014.

[11] COVID-19 Dashboard by the Center for Systems Science and Engineering (CSSE) at Johns Hopkins University (JHU). Johns Hopkins Univ 2020.

[12] Corman VM, Muth D, Niemeyer D, Drosten C. Hosts and sources of endemic human coronaviruses. Adv. Virus Res., vol. 100, Elsevier; 2018, p. 163-88.

[13] Enjuanes L, Almazán F, Sola I, Zuñiga S. Biochemical aspects of coronavirus replication and virus-host interaction. Annu Rev Microbiol 2006;60:211-30.

[14] Perlman S, Netland J. Coronaviruses post-SARS: update on replication and pathogenesis. Nat Rev Microbiol 2009;7:439-50.

[15] Graham RL, Baric RS. Recombination, reservoirs, and the modular spike: mechanisms of coronavirus cross-species transmission. J Virol 2010;84:3134-46.

[16] Li F. Receptor recognition and cross-species infections of SARS coronavirus. Antiviral Res 2013;100:246-54.

[17] Li W, Wong S-K, Li F, Kuhn JH, Huang I-C, Choe H, et al. Animal origins of the severe acute respiratory syndrome coronavirus: insight from ACE2-S-protein interactions. J Virol 2006;80:4211-9.

[18] Martinez JP, Sasse F, Brönstrup M, Diez J, Meyerhans A. Antiviral drug discovery: broad-spectrum drugs from nature. Nat Prod Rep 2015;32:29-48. 
[19] Dixon N, Wong LS, Geerlings TH, Micklefield J. Cellular targets of natural products. Nat Prod Rep 2007;24:1288-310.

[20] Cinatl J, Morgenstern B, Bauer G, Chandra P, Rabenau H, Doerr HW. Glycyrrhizin, an active component of liquorice roots, and replication of SARS-associated coronavirus. Lancet 2003;361:2045-6.

[21] Wu C-Y, Jan J-T, Ma S-H, Kuo C-J, Juan H-F, Cheng Y-SE, et al. Small molecules targeting severe acute respiratory syndrome human coronavirus. Proc Natl Acad Sci 2004;101:10012-7.

[22] Aurongzeb M, Azim MK. Antimicrobial properties of natural honey: a review of literature. Pak J Biochem Mol Biol 2011;44:118-24.

[23] Sexton NR, Smith EC, Blanc H, Vignuzzi M, Peersen OB, Denison MR. Homologybased identification of a mutation in the coronavirus RNA-dependent RNA polymerase that confers resistance to multiple mutagens. J Virol 2016;90:7415-28.

[24] Almeida JD, Berry DM, Cunningham CH, Hamre D, Hofstad MS, Mallucci L, et al. Coronaviruses 1968.

[25] Goldsmith CS, Tatti KM, Ksiazek TG, Rollin PE, Comer JA, Lee WW, et al. Ultrastructural characterization of SARS coronavirus. Emerg Infect Dis 2004;10:320.

[26] Fehr AR, Perlman S. Coronaviruses: an overview of their replication and pathogenesis. Coronaviruses, Springer; 2015, p. 1-23.

[27] Lai MMC, Cavanagh D. The molecular biology of coronaviruses. Adv. Virus Res., vol. 48, Elsevier; 1997, p. 1-100.

[28] de Groot RJ, Baker SC, Baric R, Enjuanes L, Gorbalenya AE, Holmes K V, et al. Family coronaviridae. Virus Taxon 2012:806-28.

[29] Chang C, Hou M-H, Chang C-F, Hsiao C-D, Huang T. The SARS coronavirus nucleocapsid protein-forms and functions. Antiviral Res 2014;103:39-50.

[30] Neuman BW, Kiss G, Kunding AH, Bhella D, Baksh MF, Connelly S, et al. A structural analysis of $\mathrm{M}$ protein in coronavirus assembly and morphology. J Struct Biol 2011;174:11-22.

[31] Kamitani W, Narayanan K, Huang C, Lokugamage K, Ikegami T, Ito N, et al. Severe acute respiratory syndrome coronavirus nsp1 protein suppresses host gene expression by promoting host mRNA degradation. Proc Natl Acad Sci 2006;103:12885-90.

[32] Kamitani W, Huang C, Narayanan K, Lokugamage KG, Makino S. A two-pronged strategy to suppress host protein synthesis by SARS coronavirus Nsp1 protein. Nat Struct Mol Biol 2009;16:1134. 
[33] Tanaka T, Kamitani W, DeDiego ML, Enjuanes L, Matsuura Y. Severe acute respiratory syndrome coronavirus nsp1 facilitates efficient propagation in cells through a specific translational shutoff of host mRNA. J Virol 2012;86:11128-37.

[34] Ivanov KA, Thiel V, Dobbe JC, Van Der Meer Y, Snijder EJ, Ziebuhr J. Multiple enzymatic activities associated with severe acute respiratory syndrome coronavirus helicase. J Virol 2004;78:5619-32.

[35] Ivanov KA, Ziebuhr J. Human coronavirus 229E nonstructural protein 13: characterization of duplex-unwinding, nucleoside triphosphatase, and RNA 5'triphosphatase activities. J Virol 2004;78:7833-8.

[36] Bhardwaj K, Sun J, Holzenburg A, Guarino LA, Kao CC. RNA recognition and cleavage by the SARS coronavirus endoribonuclease. J Mol Biol 2006;361:243-56.

[37] Ivanov KA, Hertzig T, Rozanov M, Bayer S, Thiel V, Gorbalenya AE, et al. Major genetic marker of nidoviruses encodes a replicative endoribonuclease. Proc Natl Acad Sci 2004;101:12694-9.

[38] Casais R, Dove B, Cavanagh D, Britton P. Recombinant avian infectious bronchitis virus expressing a heterologous spike gene demonstrates that the spike protein is a determinant of cell tropism. J Virol 2003;77:9084-9.

[39] Wickramasinghe INA, De Vries RP, Gröne A, De Haan CAM, Verheije MH. Binding of avian coronavirus spike proteins to host factors reflects virus tropism and pathogenicity. J Virol 2011;85:8903-12.

[40] Chan JF-W, Kok K-H, Zhu Z, Chu H, To KK-W, Yuan S, et al. Genomic characterization of the 2019 novel human-pathogenic coronavirus isolated from a patient with atypical pneumonia after visiting Wuhan. Emerg Microbes Infect 2020;9:221-36.

[41] Xiaolu T, Changcheng W, Xiang L, Yuhe S, Xinmin Y, Xinkai W, et al. On the origin and continuing evolution of SARS-CoV-2. Natl Sci Rev 2020.

[42] Kubo H, Yamada YK, Taguchi F. Localization of neutralizing epitopes and the receptor-binding site within the amino-terminal 330 amino acids of the murine coronavirus spike protein. J Virol 1994;68:5403-10.

[43] Cheng PKC, Wong DA, Tong LKL, Ip S-M, Lo ACT, Lau C-S, et al. Viral shedding patterns of coronavirus in patients with probable severe acute respiratory syndrome. Lancet 2004;363:1699-700.

[44] Yeager CL, Ashmun RA, Williams RK, Cardellichio CB, Shapiro LH, Look AT, et al. Human aminopeptidase $\mathrm{N}$ is a receptor for human coronavirus 229E. Nature 1992;357:420-2. 
[45] Tresnan DB, Levis R, Holmes K V. Feline aminopeptidase N serves as a receptor for feline, canine, porcine, and human coronaviruses in serogroup I. J Virol 1996;70:8669-74.

[46] Benbacer L, Kut E, Besnardeau L, Laude H, Delmas B. Interspecies aminopeptidase-N chimeras reveal species-specific receptor recognition by canine coronavirus, feline infectious peritonitis virus, and transmissible gastroenteritis virus. $\mathrm{J}$ Virol $1997 ; 71: 734-7$.

[47] Li BX, Ge JW, Li YJ. Porcine aminopeptidase $\mathrm{N}$ is a functional receptor for the PEDV coronavirus. Virology 2007;365:166-72.

[48] Hofmann H, Pyrc K, Van Der Hoek L, Geier M, Berkhout B, Pöhlmann S. Human coronavirus NL63 employs the severe acute respiratory syndrome coronavirus receptor for cellular entry. Proc Natl Acad Sci 2005;102:7988-93.

[49] Li W, Moore MJ, Vasilieva N, Sui J, Wong SK, Berne MA, et al. Angiotensinconverting enzyme 2 is a functional receptor for the SARS coronavirus. Nature $2003 ; 426: 450-4$

[50] Raj VS, Mou H, Smits SL, Dekkers DHW, Müller MA, Dijkman R, et al. Dipeptidyl peptidase 4 is a functional receptor for the emerging human coronavirus-EMC. Nature 2013;495:251-4.

[51] Nédellec P, Dveksler GS, Daniels E, Turbide C, Chow B, Basile AA, et al. Bgp2, a new member of the carcinoembryonic antigen-related gene family, encodes an alternative receptor for mouse hepatitis viruses. J Virol 1994;68:4525-37.

[52] Williams RK, Jiang G-S, Holmes K V. Receptor for mouse hepatitis virus is a member of the carcinoembryonic antigen family of glycoproteins. Proc Natl Acad Sci 1991;88:5533-6.

[53] Collins AR, Knobler RL, Powell H, Buchmeier MJ. Monoclonal antibodies to murine hepatitis virus-4 (strain JHM) define the viral glycoprotein responsible for attachment and cell-cell fusion. Virology 1982;119:358-71.

[54] Bande F, Arshad SS, Hair Bejo M, Moeini H, Omar AR. Progress and challenges toward the development of vaccines against avian infectious bronchitis. J Immunol Res $2015 ; 2015$.

[55] Williams BH, Kiupel M, West KH, Raymond JT, Grant CK, Glickman LT. Coronavirus-associated epizootic catarrhal enteritis in ferrets. J Am Vet Med Assoc 2000;217:526-30.

[56] Weiss SR, Navas-Martin S. Coronavirus pathogenesis and the emerging pathogen severe acute respiratory syndrome coronavirus. Microbiol Mol Biol Rev 2005;69:63564. 
[57] Zhou P, Fan H, Lan T, Yang X-L, Shi W-F, Zhang W, et al. Fatal swine acute diarrhoea syndrome caused by an HKU2-related coronavirus of bat origin. Nature 2018;556:255-8.

[58] Wang W, Tang J, Wei F. Updated understanding of the outbreak of 2019 novel coronavirus (2019-nCoV) in Wuhan, China. J Med Virol 2020;92:441-7.

[59] Huang C, Wang Y, Li X, Ren L, Zhao J, Hu Y, et al. Clinical features of patients infected with 2019 novel coronavirus in Wuhan, China. Lancet 2020;395:497-506.

[60] Sun P, Lu X, Xu C, Sun W, Pan B. Understanding of COVID-19 based on current evidence. J Med Virol 2020;92:548-51.

[61] Lei J, Li J, Li X, Qi X. CT imaging of the 2019 novel coronavirus (2019-nCoV) pneumonia. Radiology 2020;295:18.

[62] Letko M, Marzi A, Munster V. Functional assessment of cell entry and receptor usage for SARS-CoV-2 and other lineage B betacoronaviruses. Nat Microbiol 2020;5:562-9.

[63] Gu J, Han B, Wang J. COVID-19: gastrointestinal manifestations and potential fecaloral transmission. Gastroenterology 2020;158:1518-9.

[64] Hamming I, Timens W, Bulthuis MLC, Lely AT, Navis GJ van, van Goor H. Tissue distribution of ACE2 protein, the functional receptor for SARS coronavirus. A first step in understanding SARS pathogenesis. J Pathol A J Pathol Soc Gt Britain Irel 2004;203:631-7.

[65] Lai C-C, Shih T-P, Ko W-C, Tang H-J, Hsueh P-R. Severe acute respiratory syndrome coronavirus 2 (SARS-CoV-2) and corona virus disease-2019 (COVID-19): the epidemic and the challenges. Int J Antimicrob Agents 2020:105924.

[66] Liu Y, Li J, Feng Y. Critical care response to a hospital outbreak of the 2019-nCoV infection in Shenzhen, China 2020.

[67] Gao J, Tian Z, Yang X. Breakthrough: Chloroquine phosphate has shown apparent efficacy in treatment of COVID-19 associated pneumonia in clinical studies. Biosci Trends 2020.

[68] Luo H, Tang Q, Shang Y, Liang S, Yang M, Robinson N, et al. Can Chinese medicine be used for prevention of corona virus disease 2019 (COVID-19)? A review of historical classics, research evidence and current prevention programs. Chin J Integr Med 2020:1-8.

[69] Jean S-S, Lee P-I, Hsueh P-R. Treatment options for COVID-19: The reality and challenges. J Microbiol Immunol Infect 2020.

[70] Cunningham AC, Goh HP, Koh D. Treatment of COVID-19: old tricks for new challenges 2020 . 
[71] Chen L, Xiong J, Bao L, Shi Y. Convalescent plasma as a potential therapy for COVID-19. Lancet Infect Dis 2020;20:398-400.

[72] Shen C, Wang Z, Zhao F, Yang Y, Li J, Yuan J, et al. Treatment of 5 critically ill patients with COVID-19 with convalescent plasma. Jama 2020;323:1582-9.

[73] Said ZN, Abdelwahab KS. Antiviral replication agents. Viral Replication 2013:12744.

[74] Graham RL, Sims AC, Brockway SM, Baric RS, Denison MR. The nsp2 replicase proteins of murine hepatitis virus and severe acute respiratory syndrome coronavirus are dispensable for viral replication. J Virol 2005;79:13399-411.

[75] Ou X, Liu Y, Lei X, Li P, Mi D, Ren L, et al. Characterization of spike glycoprotein of SARS-CoV-2 on virus entry and its immune cross-reactivity with SARS-CoV. Nat Commun 2020;11:1-12.

[76] Hoffmann M, Kleine-Weber H, Schroeder S, Krüger N, Herrler T, Erichsen S, et al. SARS-CoV-2 cell entry depends on ACE2 and TMPRSS2 and is blocked by a clinically proven protease inhibitor. Cell 2020.

[77] Beutler JA. Natural products as a foundation for drug discovery. Curr Protoc Pharmacol 2009;46:9-11.

[78] Simoni IC, Manha APS, Sciessere L, Hoe VMH, Takinami VH, Fernandes MJB. Evaluation of the antiviral activity of Brazilian cerrado plants against animal viruses. Virus Rev Res 2007;12:25-31.

[79] Pa S, Mangalaa SD, Sophiea AM, Lathab CP. Antiviral and antioxidant activities of two medicinal plants. Int J Curr Sci 2012:256-61.

[80] Patwardhan B, Gautam M. Botanical immunodrugs: scope and opportunities. Drug Discov Today 2005;10:495-502.

[81] Imbert I, Guillemot J, Bourhis J, Bussetta C, Coutard B, Egloff M, et al. A second, non-canonical RNA-dependent RNA polymerase in SARS Coronavirus. EMBO J 2006;25:4933-42.

[82] Song YH, Kim DW, Curtis-Long MJ, Yuk HJ, Wang Y, Zhuang N, et al. Papain-like protease (PLpro) inhibitory effects of cinnamic amides from Tribulus terrestris fruits. Biol Pharm Bull 2014;37:1021-8.

[83] Cho JK, Curtis-Long MJ, Lee KH, Kim DW, Ryu HW, Yuk HJ, et al. Geranylated flavonoids displaying SARS-CoV papain-like protease inhibition from the fruits of Paulownia tomentosa. Bioorg Med Chem 2013;21:3051-7.

[84] Kim DW, Seo KH, Curtis-Long MJ, Oh KY, Oh J-W, Cho JK, et al. Phenolic phytochemical displaying SARS-CoV papain-like protease inhibition from the seeds of 
Psoralea corylifolia. J Enzyme Inhib Med Chem 2014;29:59-63.

[85] Lira SP de, Seleghim MHR, Williams DE, Marion F, Hamill P, Jean F, et al. A SARScoronovirus 3CL protease inhibitor isolated from the marine sponge Axinella cf. corrugata: structure elucidation and synthesis. J Braz Chem Soc 2007;18:440-3.

[86] Lin C-W, Tsai F-J, Tsai C-H, Lai C-C, Wan L, Ho T-Y, et al. Anti-SARS coronavirus 3C-like protease effects of Isatis indigotica root and plant-derived phenolic compounds. Antiviral Res 2005;68:36-42.

[87] Nguyen TTH, Woo H-J, Kang H-K, Kim Y-M, Kim D-W, Ahn S-A, et al. Flavonoidmediated inhibition of SARS coronavirus 3C-like protease expressed in Pichia pastoris. Biotechnol Lett 2012;34:831-8.

[88] Pace P, Nizi E, Pacini B, Pesci S, Matassa V, De Francesco R, et al. The monoethyl ester of meconic acid is an active site inhibitor of HCV NS5B RNA-dependent RNA polymerase. Bioorg Med Chem Lett 2004;14:3257-61.

[89] Kong L, Li S, Han X, Xiang Z, Fang X, Li B, et al. Inhibition of HCV RNA-dependent RNA polymerase activity by aqueous extract from Fructus Ligustri Lucidi. Virus Res 2007;128:9-17.

[90] Ahmed-Belkacem A, Ahnou N, Barbotte L, Wychowski C, Pallier C, Brillet R, et al. Silibinin and related compounds are direct inhibitors of hepatitis C virus RNAdependent RNA polymerase. Gastroenterology 2010;138:1112-22.

[91] Haudecoeur R, Ahmed-Belkacem A, Yi W, Fortuné A, Brillet R, Belle C, et al. Discovery of naturally occurring aurones that are potent allosteric inhibitors of hepatitis C virus RNA-dependent RNA polymerase. J Med Chem 2011;54:5395-402.

[92] Agostini ML, Andres EL, Sims AC, Graham RL, Sheahan TP, Lu X, et al. Coronavirus susceptibility to the antiviral remdesivir (GS-5734) is mediated by the viral polymerase and the proofreading exoribonuclease. MBio 2018;9.

[93] Balasuriya BWN, Rupasinghe HPV. Plant flavonoids as angiotensin converting enzyme inhibitors in regulation of hypertension. Funct Foods Heal Dis 2011;1:172-88.

[94] Kang DG, Lee YS, Kim HJ, Lee YM, Lee HS. Angiotensin converting enzyme inhibitory phenylpropanoid glycosides from Clerodendron trichotomum. J Ethnopharmacol 2003;89:151-4.

[95] Hyun SK, Lee H, Kang SS, Chung HY, Choi JS. Inhibitory activities of Cassia tora and its anthraquinone constituents on angiotensin-converting enzyme. Phyther Res An Int J Devoted to Pharmacol Toxicol Eval Nat Prod Deriv 2009;23:178-84.

[96] Ho T-Y, Wu S-L, Chen J-C, Li C-C, Hsiang C-Y. Emodin blocks the SARS coronavirus spike protein and angiotensin-converting enzyme 2 interaction. Antiviral 
Res 2007;74:92-101.

[97] Long Y-Q, Lee S-L, Lin C-Y, Enyedy IJ, Wang S, Li P, et al. Synthesis and evaluation of the sunflower derived trypsin inhibitor as a potent inhibitor of the type II transmembrane serine protease, matriptase. Bioorg Med Chem Lett 2001;11:2515-9.

[98] Basak A, Cooper S, ROBERGE AG, BANIK UK, CHRÉTIEN M, SEIDAH NG. Inhibition of proprotein convertases-1,-7 and furin by diterpines of Andrographis paniculata and their succinoyl esters. Biochem J 1999;338:107-13.

[99] Lalou C, Basak A, Mishra P, Mohanta BC, Banik R, Dinda B, et al. Inhibition of tumor cells proliferation and migration by the flavonoid furin inhibitor isolated from Oroxylum indicum. Curr Med Chem 2013;20:583-91.

[100] Miller B, Friedman AJ, Choi H, Hogan J, McCammon JA, Hook V, et al. The marine cyanobacterial metabolite gallinamide $\mathrm{A}$ is a potent and selective inhibitor of human cathepsin L. J Nat Prod 2014;77:92-9.

[101] de Sousa LRF, Wu H, Nebo L, Fernandes JB, da Silva MF das GF, Kiefer W, et al. Natural products as inhibitors of recombinant cathepsin L of Leishmania mexicana. Exp Parasitol 2015;156:42-8.

[102] Ramalho SD, De Sousa LRF, Nebo L, Maganhi SH, Caracelli I, Zukerman-Schpector $\mathrm{J}$, et al. Triterpenoids as novel natural inhibitors of human cathepsin L. Chem Biodivers 2014;11:1354-63.

[103] Vázquez MJ, Albarrán MI, Espada A, Rivera-Sagredo A, Díez E, Hueso-Rodríguez JA. A new destruxin as inhibitor of vacuolar-type H+-ATPase of Saccharomyces cerevisiae. Chem Biodivers 2005;2:123-30.

[104] Hassfeld J, Fares C, Steinmetz H, Carlomagno T, Menche D. Stereochemical Determination of Archazolid A and B, Highly Potent Vacuolar-Type ATPase Inhibitors from the Myxobacterium Archangium g ephyra. Org Lett 2006;8:4751-4.

[105] Huss M, Ingenhorst G, König S, Gaßel M, Dröse S, Zeeck A, et al. Concanamycin A, the specific inhibitor of V-ATPases, binds to the Vo subunit c. J Biol Chem 2002;277:40544-8.

[106] Huss M, Wieczorek H. Inhibitors of V-ATPases: old and new players. J Exp Biol 2009;212:341-6.

[107] Yi L, Li Z, Yuan K, Qu X, Chen J, Wang G, et al. Small molecules blocking the entry of severe acute respiratory syndrome coronavirus into host cells. J Virol 2004;78:11334-9.

[108] Li S, Chen C, Zhang H, Guo H, Wang H, Wang L, et al. Identification of natural compounds with antiviral activities against SARS-associated coronavirus. Antiviral 
Res 2005;67:18-23.

[109] Wen C-C, Kuo Y-H, Jan J-T, Liang P-H, Wang S-Y, Liu H-G, et al. Specific plant terpenoids and lignoids possess potent antiviral activities against severe acute respiratory syndrome coronavirus. J Med Chem 2007;50:4087-95.

[110] Yang Q-Y, Tian X-Y, Fang W-S. Bioactive coumarins from Boenninghausenia sessilicarpa. J Asian Nat Prod Res 2007;9:59-65.

[111] Lau K-M, Lee K-M, Koon C-M, Cheung CS-F, Lau C-P, Ho H-M, et al. Immunomodulatory and anti-SARS activities of Houttuynia cordata. J Ethnopharmacol 2008;118:79-85.

[112] Zhuang M, Jiang H, Suzuki Y, Li X, Xiao P, Tanaka T, et al. Procyanidins and butanol extract of Cinnamomi Cortex inhibit SARS-CoV infection. Antiviral Res 2009;82:7381.

[113] Ryu YB, Jeong HJ, Kim JH, Kim YM, Park J-Y, Kim D, et al. Biflavonoids from Torreya nucifera displaying SARS-CoV 3CLpro inhibition. Bioorg Med Chem 2010;18:7940-7.

[114] Yu M-S, Lee J, Lee JM, Kim Y, Chin Y-W, Jee J-G, et al. Identification of myricetin and scutellarein as novel chemical inhibitors of the SARS coronavirus helicase, nsP13. Bioorg Med Chem Lett 2012;22:4049-54.

[115] Park J-Y, Kim JH, Kim YM, Jeong HJ, Kim DW, Park KH, et al. Tanshinones as selective and slow-binding inhibitors for SARS-CoV cysteine proteases. Bioorg Med Chem 2012;20:5928-35. 
Figures and Tables 


\section{A. Schematic representation of Coronavirus}

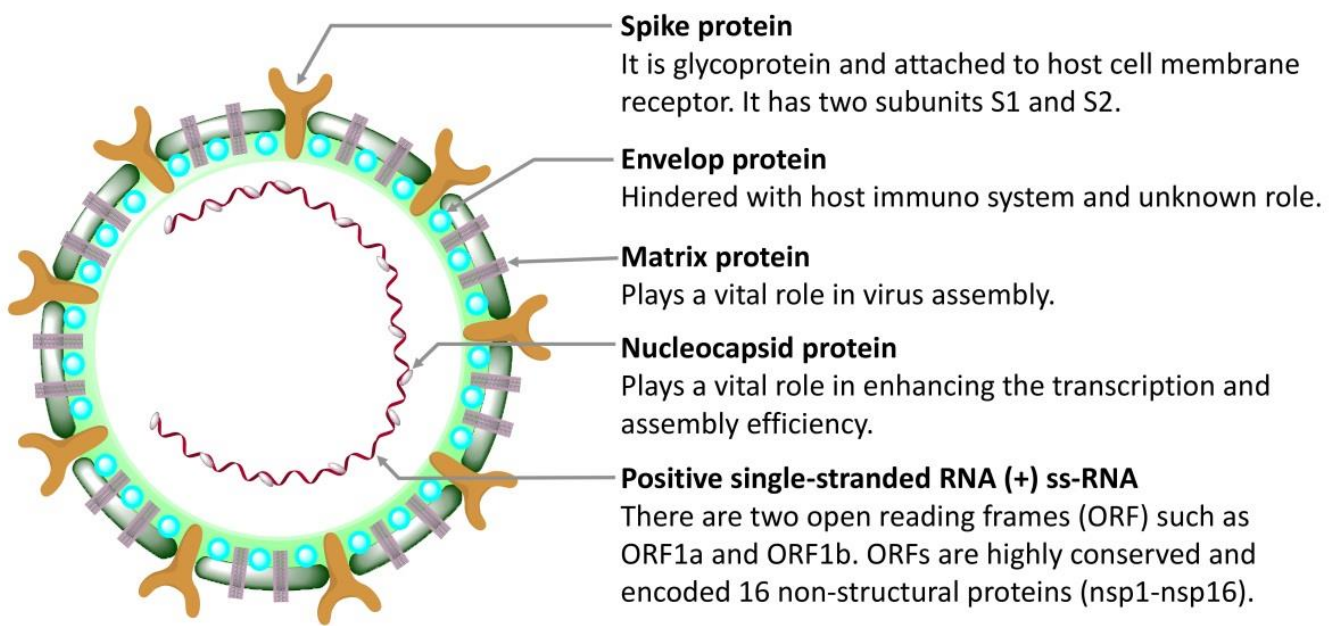

B. Mode of action and pathogenesis

Bat, Swine, Civet, Mouse

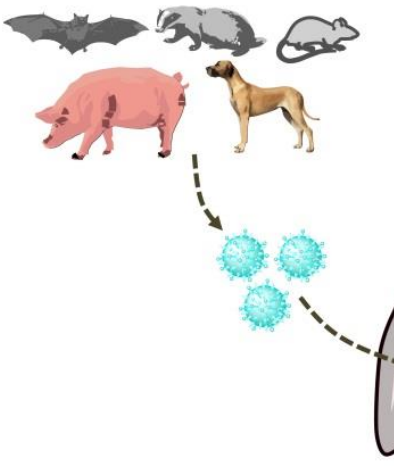

Host Cell Receptors

The human pathogenic coronaviruses such as HCoV-NL63 and SARS-CoV interact with angiotensin converting enzyme 2 (ACE2) and MERS-CoV interact with dipeptidyl-peptidase 4 (DPP4).

\section{Symptoms}

Cough, fever $\left(39.0^{\circ} \mathrm{C}\right)$, difficulties in breathing fatigue, headache, diarrhea, sputum formation, haemoptysis, and lymphopenia

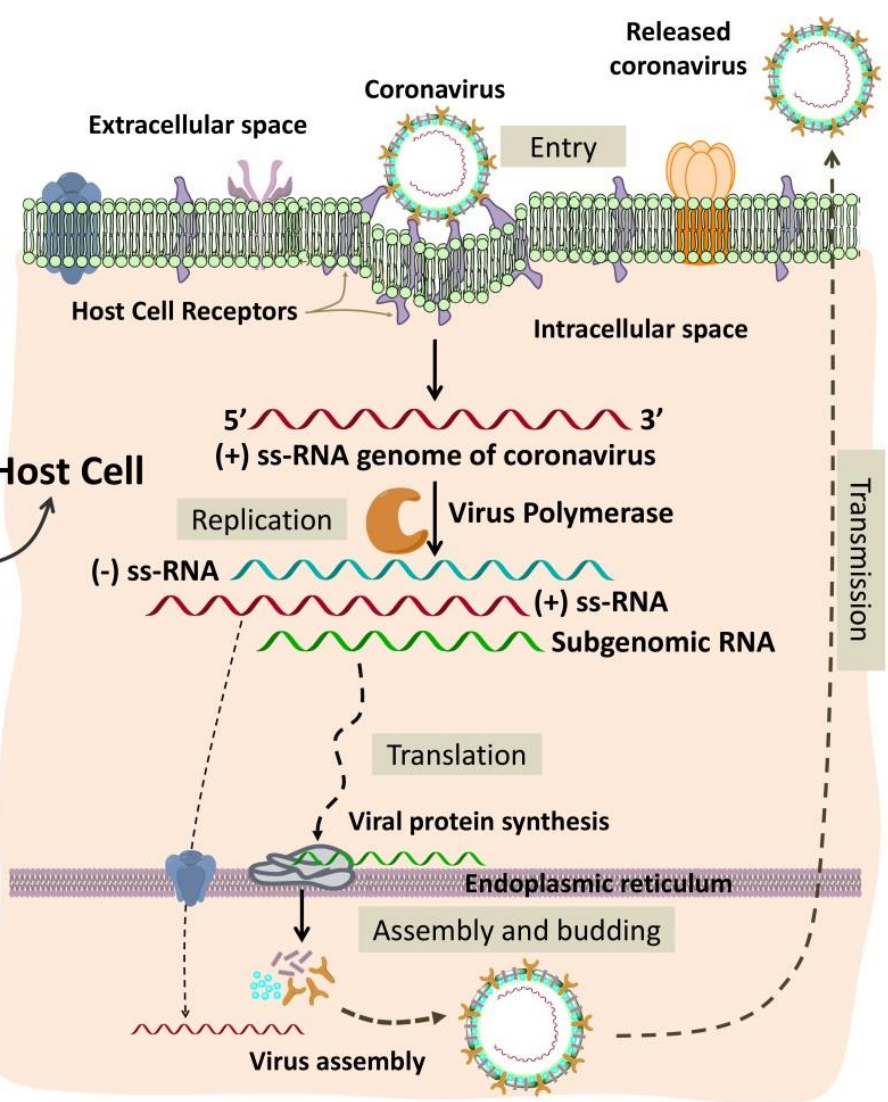

Figure 1. A) Diagrammatic representation of coronavirus, which is composed of the structural proteins, including spike protein, envelope protein, matrix protein, and nucleo-capsid, and inside the capsule, it has positive single-stranded RNA (+) ss-RNA). B) Mode of action and pathogenesis of coronaviruses. The bats are the reservoir of several types of coronaviruses and dog, mouse, swine, and civet are the transmission vectors for coronavirus contagion into the humans. Coronaviruses infection in humans causes respiratory syndrome such as SARS, 
MERS, and COVID-19. Coronaviruses primarily act on the respiratory system and gastrointestinal tract, interact with host cells by the membrane enzymes mostly peptidases, which is a critical phase for virus entry. After that replication, translation, and assembly of viral proteins and genome has carried out inside the endoplasmic reticulum and cytoplasm following released by exocytosis from the host cell. 

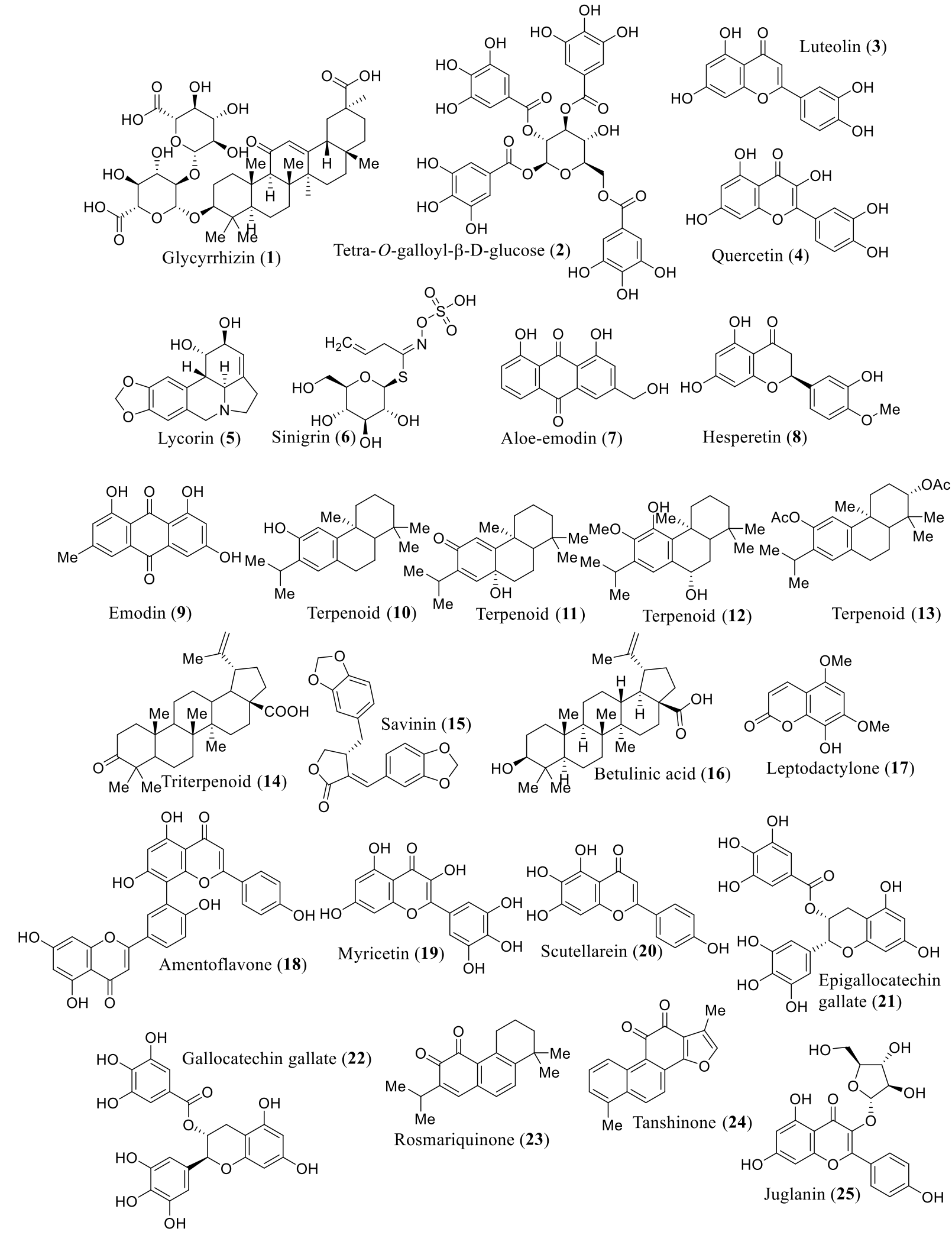

Figure 2. Selected bioactive natural products against coronaviruses. 
A
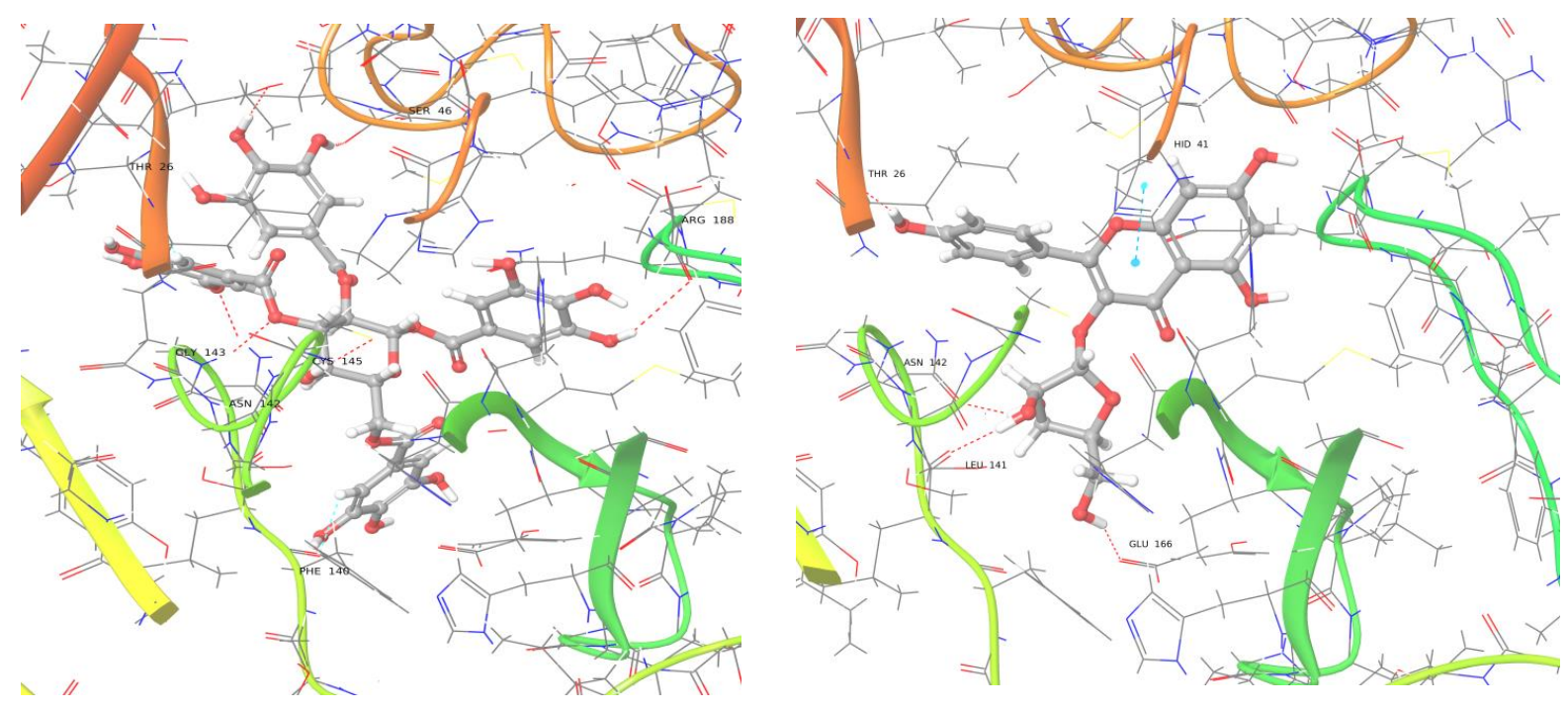

B
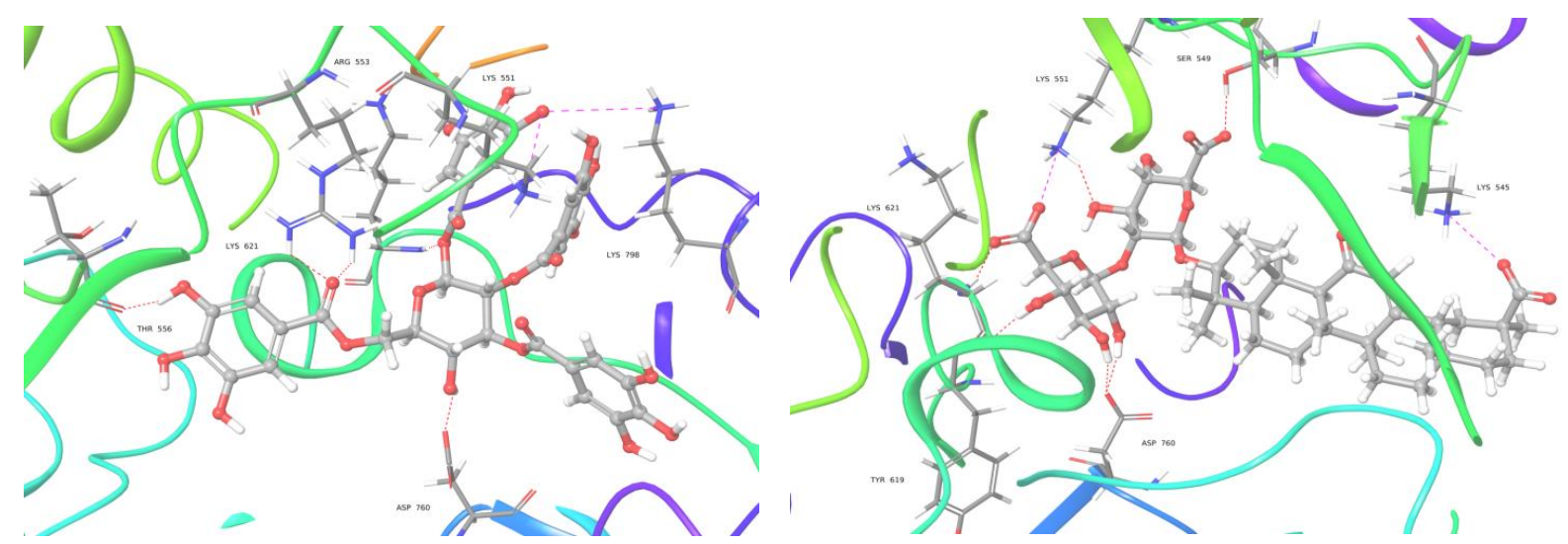

Figure 3. A) $3 \mathrm{D}$-interaction of Tetra-O-galloyl- $\beta$-D-glucose $(-12.20 \mathrm{Kcal} / \mathrm{mol})$ and juglanin $(-8.96 \mathrm{Kcal} / \mathrm{mol})$ against main protease Enzyme (6lu7); B) 3D-interaction of Tetra-O-galloyl$\beta$-D-glucose $(-11.74 \mathrm{Kcal} / \mathrm{mol})$ and glycyrrhizin $(-7.77 \mathrm{Kcal} / \mathrm{mol})$ against RdRp enzyme (7BV2). 


\section{Table 1}

Therapeutic target and its natural inhibitor

\begin{tabular}{|c|c|c|c|}
\hline Targets & Description & Natural molecule modulators & Ref. \\
\hline $\begin{array}{l}\text { Papain-like protease } \\
\left(P L^{\text {pro }}\right)\end{array}$ & $\begin{array}{l}\text { Essential for CoV replication, and } \\
\text { involved in the proteolytic } \\
\text { processing of Nsp1-3 }\end{array}$ & $\begin{array}{l}\text { Cinnamic amides, ferulic acid, tomentin A, } \\
\text { tomentin B, tomentin C, tomentin D, tomentin } \\
\text { E, bavachinin, neobavaisoflavone, } \\
\text { isobavachalcone, } 4^{\prime} \text {-O-methyl-bavachalcone, } \\
\text { psoralidin, and corylifol A. }\end{array}$ & $\begin{array}{l}81] \\
{[82]} \\
{[83]} \\
{[84]}\end{array}$ \\
\hline $\begin{array}{l}\text { Main protease }\left(M^{\text {pro }} / 3 C L-\right. \\
\text { Protease) }\end{array}$ & $\begin{array}{l}\text { Function as proteolytic processing } \\
\text { of Nsp4-16 including RdRp and } \\
\text { replicase-transcriptase complex } \\
\text { (RTC). }\end{array}$ & $\begin{array}{l}\text { Esculetin-4-carboxylic acid methyl ester, } \\
\text { esculetin-4-carboxylic acid ethyl ester, aloe- } \\
\text { emodin, beta-sitosterol, indigo, hesperetin, } \\
\text { sinigrin, quercetin, gallocatechin gallate, and } \\
\text { epigallocatechin gallate. }\end{array}$ & $\begin{array}{l}{[85]} \\
{[86]} \\
{[87]}\end{array}$ \\
\hline $\begin{array}{l}\text { RNA-dependent } R N A \\
\text { polymerase (RdRp/nsp12) }\end{array}$ & $\begin{array}{l}\text { It is a supra-molecular complex } \\
\text { associated with processivity clamps } \\
\text { (nsp7 and nsp8), exoribonuclease, } \\
\text { RNA helicase, and 5'- } \\
\text { triphosphatase. Replication of the } \\
\text { viral RNA and transcription of sub- } \\
\text { genomic RNA. }\end{array}$ & $\begin{array}{l}\text { Monoethyl ester of meconic acid, extract from } \\
\text { Fructus Ligustri Lucidi, Silibinin A, silibinin } \\
\text { B, and aureusidin. }\end{array}$ & $\begin{array}{l}88] \\
{[89]} \\
{[90]} \\
{[91]}\end{array}$ \\
\hline $\begin{array}{l}\text { Exoribonuclease } \\
\text { (Exo/nsp14) }\end{array}$ & $\begin{array}{l}\text { Function as } 3^{\prime}-5^{\prime} \text { proofreading } \\
\text { ribonuclease. Hammering ExoN } \\
\text { activity results enhance the antiviral } \\
\text { potency of remdesivir. }\end{array}$ & NA & {$[92]$} \\
\hline $\begin{array}{l}\text { Angiotensin-converting } \\
\text { enzyme } 2 \text { (ACE2) }\end{array}$ & $\begin{array}{l}\text { It is a transmembrane receptor with } \\
\text { peptidase activity to cleave } \\
\text { angiotensin II and other peptide } \\
\text { hormones. ACE2 is interacting with } \\
\text { the spike protein of SARS-CoV-2. } \\
\text { To prevent ACE2-spike protein } \\
\text { coupling is considered an ideal } \\
\text { model for antiviral therapeutics. }\end{array}$ & $\begin{array}{l}\text { Quercetin, quercetin-3-glucoside, quercetin-3- } \\
\text { galactoside, cyanidin-3-galactoside, acteoside, } \\
\text { Emodin, leucosceptoside A, martynoside, } \\
\text { acteoside isomer, isomartynoside, } \\
\text { gluco-aurantioobtusin. }\end{array}$ & $\begin{array}{l}{[93]} \\
{[94]} \\
{[95]} \\
{[96]}\end{array}$ \\
\hline $\begin{array}{l}\text { Transmembrane serine } \\
\text { protease } 2 \text { (TMPRSS2) }\end{array}$ & $\begin{array}{l}\text { TMPRSS } 2 \text { is a protease involved in } \\
\text { cleaves of ACE2 and the spike } \\
\text { protein. It assists in viral entry into } \\
\text { the host lung cells. Inhibition of } \\
\text { TMPRSS } 2 \text { results impedes viral } \\
\text { entry into host cells. }\end{array}$ & Sunflower trypsin inhibitor (SFTI-1). & $\begin{array}{l}{[76]} \\
{[97]}\end{array}$ \\
\hline Furin & $\begin{array}{l}\text { It is a protease that proteolyzed } \\
\text { inactive proteins precursor into } \\
\text { their active form. Notably, it } \\
\text { cleaving viral envelope proteins. }\end{array}$ & $\begin{array}{l}\text { Catechins, gallic acid, neoandrographolide, } \\
\text { Andrographolide, baicalein, quercetin, } \\
\text { phlogantholide, and epigallocatechin gallate. }\end{array}$ & $\begin{array}{l}98] \\
{[99]}\end{array}$ \\
\hline$C D 147$ & $\begin{array}{l}\text { It is an alternative receptor for the } \\
\text { SARS-CoV- } 2 \text {. }\end{array}$ & NA & [99] \\
\hline Cathepsin L (CTSL) & $\begin{array}{l}\text { Cathepsin } \mathrm{L} \text { is a } \mathrm{pH} \text {-dependent } \\
\text { protease localized in the lysosome } \\
\text { that mediates the entry of the virus } \\
\text { via endosomes. }\end{array}$ & $\begin{array}{l}\text { Gallinamide A gathisflavone, tetrahydro- } \\
\text { robustaflavone, 3-oxo-urs-12-en-28-oic acid, } \\
\text { 3- epiursolic acid, 3-(hydroxyimino) oleanolic } \\
\text { acid, and 3-(hydroxyl-imino) masticadienoic }\end{array}$ & $\begin{array}{l}{[100]} \\
{[101]} \\
{[102]}\end{array}$ \\
\hline
\end{tabular}




\begin{tabular}{|l|l|l|l|}
\hline & & acid. & \\
\hline $\begin{array}{l}\text { Vacuolar-type } H^{+} \text {ATPase } \\
\text { (V-ATPase) }\end{array}$ & $\begin{array}{l}\text { V-ATPase is a proton pump located } \\
\text { into endosomes an lysosomes, }\end{array}$ & $\begin{array}{l}\text { Destruxins, Archazolid A, Archazolid B, } \\
\text { concanamycin A, bafilomycin A1, 11-deoxy- }\end{array}$ & {$[103]$} \\
& which minimized the pH. At acidic & apicularen, Apicularen B, Open apicularen, & {$[105]$} \\
& pH cathepsins required for the & apicularen A, salicylihalamide A, lobatamide & {$[106]$} \\
& endocytosis of SARS-CoV-2. & A, apicularen A, cruentaren, Benzolactone & \\
& & enamides, oximidine I. & \\
\hline
\end{tabular}




\section{Table 2}

Experimentally screened anti-coronavirus natural molecules/extract

\begin{tabular}{|c|c|c|c|c|}
\hline Molecules/ extract & Source & Targets & Activity & Ref. \\
\hline Glycyrrhizin & liquorice roots & Replication unit & The $\mathrm{IC}_{50}$ value is $316-625 \mathrm{mg} / \mathrm{L}$ & [20] \\
\hline $\begin{array}{l}\text { Tetra- } O \text {-galloyl- } \beta \text { - } \\
\text { D-glucose }\end{array}$ & & & $\begin{array}{l}\text { An } \mathrm{EC}_{50} \text { value is } 4.5 \mu \mathrm{M} \text { and a selective } \\
\text { index is } 240 .\end{array}$ & {$[107]$} \\
\hline Quercetin & & & The $\mathrm{EC}_{50}$ is $83.4 \mu \mathrm{M}$ & [107] \\
\hline $\begin{array}{l}\text { Lycoris radiata } \\
\text { extract (lycorine) }\end{array}$ & Lycoris radiata, & & The $\mathrm{EC}_{50}$ value of $2.4 \pm 0.2 \mu \mathrm{g} / \mathrm{ml}$. & {$[108]$} \\
\hline $\begin{array}{l}\text { Isatis indigotica root } \\
\text { extract }\end{array}$ & Isatis indigotica & $3 \mathrm{CL}$ protease & $\begin{array}{l}\text { The } \mathrm{IC}_{50} \text { value is } 53.8 \pm 4.2 \mu \mathrm{g} / \mathrm{ml} \text { by the } \\
\text { cell-free assay and } 191.6 \pm 8.2 \mu \mathrm{g} / \mathrm{ml} \text { by } \\
\text { the cell-based assay. }\end{array}$ & [86] \\
\hline Indigo & Isatis indigotica & $3 \mathrm{CL}$ protease & $\begin{array}{l}\text { The } \mathrm{IC}_{50} \text { value is } 300 \mu \mathrm{M} \text { by the cell-free } \\
\text { assay and } 752 \mu \mathrm{M} \text { by the cell-based } \\
\text { assay. }\end{array}$ & [86] \\
\hline Indirubin & Isatis indigotica & 3CL protease & $\begin{array}{l}\text { The } \mathrm{IC}_{50} \text { value is } 293 \mu \mathrm{M} \text { by the cell-free } \\
\text { assay. }\end{array}$ & [86] \\
\hline Indican & Isatis indigotica & 3CL protease & $\begin{array}{l}\text { The } \mathrm{IC}_{50} \text { value is } 112 \mu \mathrm{M} \text { by the cell-free } \\
\text { assay. }\end{array}$ & {$[86]$} \\
\hline Sinigrin & Isatis indigotica & 3CL protease & $\begin{array}{l}\text { The } \mathrm{IC}_{50} \text { value is } 121 \mu \mathrm{M} \text { by the cell-free } \\
\text { assay and } 217 \mu \mathrm{M} \text { by the cell-based } \\
\text { assay }\end{array}$ & [86] \\
\hline$\beta$-sitosterol & Isatis indigotica & $3 \mathrm{CL}$ protease & $\begin{array}{l}\text { The } \mathrm{IC}_{50} \text { value is } 115 \mu \mathrm{M} \text { by the cell- } \\
\text { free assay and } 1210 \mu \mathrm{M} \text { by the cell-based } \\
\text { assay }\end{array}$ & {$[86]$} \\
\hline Aloe-emodin & & $3 \mathrm{CL}$ protease & $\begin{array}{l}\text { The } \mathrm{IC}_{50} \text { value is } 132 \mu \mathrm{M} \text { by the cell-free } \\
\text { assay and } 366 \mu \mathrm{M} \text { by the cell-based } \\
\text { assay }\end{array}$ & [86] \\
\hline Hesperetin & & 3CL protease & $\begin{array}{l}\text { The } \mathrm{IC}_{50} \text { value is } 60 \mu \mathrm{M} \text { by the cell-free } \\
\text { assay and } 8.3 \mu \mathrm{M} \text { by the cell-based assay }\end{array}$ & [86] \\
\hline Daidzein & & 3CL protease & $\begin{array}{l}\text { The } \mathrm{IC}_{50} \text { value is } 105 \mu \mathrm{M} \text { by the cell-free } \\
\text { assay. }\end{array}$ & [86] \\
\hline Emodin & $\begin{array}{l}\text { Rheum officinale and } \\
\text { Polygonum multiflorum }\end{array}$ & $\begin{array}{l}\text { S protein and } \\
\text { ACE2 interaction }\end{array}$ & The $\mathrm{IC}_{50}$ value is $200 \mu \mathrm{M}$ & [96] \\
\hline Chrysin & $\begin{array}{l}\text { Rheum officinale and } \\
\text { Polygonum multiflorum }\end{array}$ & $\begin{array}{l}\text { S protein and } \\
\text { ACE2 interaction }\end{array}$ & The $\mathrm{IC}_{50}$ value is $400 \mu \mathrm{M}$ & [96] \\
\hline $\begin{array}{l}\text { Radix et Rhizoma } \\
\text { Rhei, Radix Polygoni } \\
\text { multiflori, and Caulis } \\
\text { Polygoni multiflori } \\
\text { extract }\end{array}$ & $\begin{array}{l}\text { Radix et Rhizoma Rhei, } \\
\text { Radix Polygoni } \\
\text { multiflori, and } \\
\text { Caulis Polygoni } \\
\text { multiflori }\end{array}$ & $\begin{array}{l}\text { S protein and } \\
\text { ACE2 interaction }\end{array}$ & $\begin{array}{l}\text { The } \mathrm{IC}_{50} \text { value ranged from } 1 \text { to } 10 \\
\mu \mathrm{g} / \mathrm{ml} .\end{array}$ & [96] \\
\hline Ferruginol & & & $\begin{array}{l}\text { The } \mathrm{CC}_{50} 80.4 \mu \mathrm{M}, \mathrm{EC}_{50} 1.39 \mu \mathrm{M} \text {, and } \\
\text { selective index are } 58.0 \text {. }\end{array}$ & [109] \\
\hline Dehydroabieta-7-one & & & $\begin{array}{l}\mathrm{A} \mathrm{CC}_{50} 305.1 \mu \mathrm{M}, \mathrm{EC}_{50} 4.00 \mu \mathrm{M} \text {, and } \\
\text { selective index are } 76.3 .\end{array}$ & [109] \\
\hline $\begin{array}{l}6,7- \\
\text { dehydroroyleanone }\end{array}$ & & & $\begin{array}{l}\text { The } \mathrm{CC}_{50} 89.7 \mu \mathrm{M}, \mathrm{EC}_{50} 5.55 \mu \mathrm{M} \text {, and } \\
\text { selective index are 16.2. }\end{array}$ & [109] \\
\hline
\end{tabular}




\begin{tabular}{|c|c|c|c|c|}
\hline$\alpha$-cadino & & & $\begin{array}{l}\text { The } \mathrm{CC}_{50} 76.8 \mu \mathrm{M}, \mathrm{EC}_{50} 4.44 \mu \mathrm{M} \text {, and } \\
\text { selective index are 17.3. }\end{array}$ & [109] \\
\hline Honokiol & & & $\begin{array}{l}\text { The } \mathrm{IC}_{50} \text { value is }>100 \mu \mathrm{M}, \mathrm{CC}_{50} 88.9 \\
\mu \mathrm{M}, \mathrm{EC}_{50} 6.50 \mu \mathrm{M} \text { and selective index is } \\
\text { 13.7. }\end{array}$ & [109] \\
\hline Magnolol & & & $\begin{array}{l}\text { The } \mathrm{CC}_{50} 68.3 \mu \mathrm{M}, \mathrm{EC}_{50} 3.80 \mu \mathrm{M} \text { and } \\
\text { selective index is } 18.0 \text {. }\end{array}$ & [109] \\
\hline Niclosamide & & & $\begin{array}{l}\text { The } \mathrm{CC}_{50} 22.1 \mu \mathrm{M}, \mathrm{EC}_{50}<0.1 \mu \mathrm{M} \text { and } \\
\text { selective index is }>221 .\end{array}$ & [109] \\
\hline Valinomycin & & & $\begin{array}{l}\text { The } \mathrm{CC}_{50} 67.5 \mu \mathrm{M}, \mathrm{EC}_{50} 1.63 \mu \mathrm{M} \text { and } \\
\text { selective index is } 41.4\end{array}$ & [109] \\
\hline Betulinic acid & & 3CL Protease & The $\mathrm{IC}_{50}$ value is $10 \mu \mathrm{M}$ & [109] \\
\hline Betulonic acid & & 3CL Protease & The $\mathrm{IC}_{50}$ value is $>100 \mu \mathrm{M}$ & [109] \\
\hline Savinin & & 3CL Protease & The $\mathrm{IC}_{50}$ value is $25 \mu \mathrm{M}$ & [109] \\
\hline Curcumin & & 3CL Protease & The $\mathrm{IC}_{50}$ value is $40 \mu \mathrm{M}$ & [109] \\
\hline Niclosamide & & 3CL Protease & The $\mathrm{IC}_{50}$ value is $40 \mu \mathrm{M}$ & [109] \\
\hline Leptodactylone & $\begin{array}{l}\text { Boenninghausenia } \\
\text { sessilicarpa }\end{array}$ & & $\begin{array}{l}\text { Protective activity against Vero-E6 cells } \\
\text { infected by SARS-CoV at a } \\
\text { concentration of } 100 \mu \mathrm{g} / \mathrm{ml}\end{array}$ & {$[110]$} \\
\hline $\begin{array}{l}\text { water fraction of } \\
\text { Houttuynia cordata }\end{array}$ & Houttuynia cordata & $\begin{array}{l}\text { 3CL protease and } \\
\text { RdRp }\end{array}$ & $\begin{array}{l}\text { It has shown biphasic action i.e. it } \\
\text { reduces viral replication as well as helps } \\
\text { in activating immunity to prevent viral } \\
\text { infection. }\end{array}$ & {$[111]$} \\
\hline $\begin{array}{l}\text { The fraction of } \\
\text { Cinnamomi Cortex }\end{array}$ & Cinnamomi Cortex & & $\begin{array}{l}\text { The } \mathrm{IC}_{50} \text { value of } n \text {-Butanol fraction } \\
(7.8 \pm 0.3 \mu \mathrm{g} / \mathrm{ml}) \\
\text { The } \mathrm{IC}_{50} \text { value of Ethanol fraction } \\
(10.7 \pm 04 \mu \mathrm{g} / \mathrm{ml})\end{array}$ & [112] \\
\hline $\begin{array}{l}\text { Biflavoneamentoflav } \\
\text { one }\end{array}$ & Torreya nucifera & 3CL Protease & The $\mathrm{IC}_{50}$ value is $8.3 \mu \mathrm{M}$ & [113] \\
\hline Myricetin & Chromadex & Nsp13 & $\begin{array}{l}\text { Inhibited the } 90 \% \text { of ATPase activity of } \\
\text { nsP13 at a } 10 \mu \mathrm{M} \text { concentration. }\end{array}$ & [114] \\
\hline Scutellarein & Scutettaria baicalensis & Nsp13 & $\begin{array}{l}\text { Inhibited the } 90 \% \text { of ATPase activity of } \\
\text { nsP13 at a } 10 \mu \mathrm{M} \text { concentration. }\end{array}$ & [114] \\
\hline $\begin{array}{l}\text { Quercetin, } \\
\text { epigallocatechin } \\
\text { gallate, gallocatechin } \\
\text { gallate }\end{array}$ & Pichia pastoris & 3CL Protease & $\begin{array}{l}\text { The } \mathrm{IC}_{50} \text { values of quercetin }(73 \mu \mathrm{M}) \text {, } \\
\text { epigallocatechin gallate, }(73 \mu \mathrm{M}) \text { and } \\
\text { gallocatechin gallate }(47 \mu \mathrm{M}) \text { with } \mathrm{K} i \\
\text { value of } 25 \pm 1.7 \mu \mathrm{M} \text {. }\end{array}$ & {$[87]$} \\
\hline Tanshinone I & Salvia miltiorrhiza & $3 \mathrm{CL}^{\mathrm{pro}}$ and $\mathrm{PL}^{\mathrm{pro}}$ & $\begin{array}{l}\text { The good inhibitory activity even at } 0.7 \\
\mu \mathrm{M} \text { concentration by a deubiquitinating } \\
\text { mechanism with good selectivity. }\end{array}$ & [115] \\
\hline Rosmariquinone & Salvia miltiorrhiza & $3 C L^{\text {pro }}$ and $P L^{\text {pro }}$ & $\begin{array}{l}\text { It possesses different kinetic mechanisms } \\
\text { as well as slow \& reversible inhibition. }\end{array}$ & [115] \\
\hline
\end{tabular}




\section{Table 3}

Docking score \& ADME parameters of Anti-SARS candidates (Bold text shows recommended values)

\begin{tabular}{|c|c|c|c|c|c|c|c|c|c|c|c|}
\hline \multirow{2}{*}{ Natural candidate } & \multicolumn{2}{|c|}{ Docking Score } & \multirow{2}{*}{$\begin{array}{c}\operatorname{LogKp} \\
(-8.0- \\
1.0)\end{array}$} & \multirow{2}{*}{$\begin{array}{l}\text { PHOA } \\
(<25 \\
\text { poor, } \\
>80 \\
\text { good })\end{array}$} & \multirow{2}{*}{$\begin{array}{l}\text { PCaco2 } \\
(<25 \\
\text { poor, } \\
>500 \\
\text { great })\end{array}$} & \multirow{2}{*}{$\begin{array}{l}\text { Log } \\
\text { Khsa } \\
(-1.5 \\
-1.5 \\
)\end{array}$} & \multirow{2}{*}{$\begin{array}{c}\log S(- \\
6.5- \\
0.5)\end{array}$} & \multirow{2}{*}{$\begin{array}{l}\text { PMDC } \\
\text { K } \\
(<25 \text { po } \\
\text { or, } \\
>500 \\
\text { great })\end{array}$} & \multirow{2}{*}{$\begin{array}{l}\text { Rule } \\
\text { of } \\
\text { five }\end{array}$} & \multirow{2}{*}{$\begin{array}{l}\text { QPlo } \\
\text { gHE } \\
\text { RG } \\
(<5)\end{array}$} & \multirow{2}{*}{$\begin{array}{c}\text { HB-accept } \\
(2.0-20.0) \\
\text { HB-donate } \\
(0.0-6.0)\end{array}$} \\
\hline & $\begin{array}{l}\mathrm{M}^{\mathrm{pro}} \\
(6 \mathrm{lu} 7)\end{array}$ & $\begin{array}{l}\text { RdRp } \\
\text { (7bv2) }\end{array}$ & & & & & & & & & \\
\hline $\begin{array}{l}\text { Tetra- } O \text {-galloyl- } \beta \text { - } \\
\text { D-glucose }\end{array}$ & -12.20 & -11.74 & -12.19 & 0.0 & 0.001 & -1.24 & -4.53 & 0 & 3 & $\overline{-}$ & 20.4/13 \\
\hline Juglanin & -8.96 & -4.97 & -5.72 & 29.02 & 9.41 & -0.65 & -2.78 & 3.2 & 1 & -5.23 & $11.3 / 5$ \\
\hline $\begin{array}{l}\text { Epigallocatechin } \\
\text { gallate }\end{array}$ & -8.35 & -7.13 & -7.54 & 0.0 & 1.03 & -0.44 & -3.49 & 0.3 & 2 & -5.62 & 8.8/8 \\
\hline Myricetin & -7.33 & -5.67 & -6.38 & 27.43 & 6.97 & -0.49 & -2.64 & 2.3 & 1 & -4.97 & $6 / 5$ \\
\hline Scutellarein & -7.18 & -3.94 & -4.68 & 63.31 & 50.80 & -0.2 & -3.03 & 19.8 & 0 & -5.02 & $4.5 / 3$ \\
\hline Quercetin & $\begin{array}{l}-6.69 \\
\end{array}$ & -4.83 & $\begin{array}{l}-5.49 \\
\end{array}$ & 52.20 & 19.29 & $\begin{array}{l}-0.34 \\
\end{array}$ & $\begin{array}{l}-2.88 \\
\end{array}$ & 6.9 & 0 & -5.07 & $5.3 / 4$ \\
\hline Luteolin & -6.38 & -4.14 & -4.86 & 61.49 & 42.00 & -0.20 & -3.06 & 16.1 & 0 & -5.02 & $4.5 / 3$ \\
\hline Aloe-emodin & -6.05 & -3.52 & -4.49 & 66.29 & 79.02 & -0.31 & -2.59 & 31.9 & 0 & -4.51 & $5.2 / 1$ \\
\hline $\begin{array}{l}\text { Gallocatechin } \\
\text { gallate }\end{array}$ & -5.89 & -7.08 & -7.3 & 2.01 & 1.31 & -0.43 & -3.35 & 0.4 & 2 & -7.30 & $8.8 / 8$ \\
\hline Hesperetin & -5.67 & -4.11 & -4.07 & 75.40 & 132.07 & 0.02 & -3.73 & 55.5 & 0 & -4.94 & $4.8 / 2$ \\
\hline Sinigrin & -5.41 & -6.14 & -6.27 & 21.29 & 1.89 & -1.47 & -0.94 & 1.05 & 0 & -1.95 & $14 / 5$ \\
\hline Emodin & -5.25 & -2.05 & -4.71 & 68.32 & 79.84 & -0.10 & -3.05 & 32.2 & 0 & -4.33 & $4.3 / 1$ \\
\hline Amentoflavone & -4.51 & -5.16 & -6.33 & 24.46 & 2.46 & 0.68 & -6.79 & 0.8 & 2 & -7.27 & $7.5 / 4$ \\
\hline Laptodactylone & -4.23 & -2.96 & -3.11 & 83.17 & 645.66 & -0.46 & -2.09 & 308.3 & 0 & -3.94 & $4.8 / 1$ \\
\hline Savinin & -4.11 & -1.40 & -1.66 & 100 & 2491.65 & -0.53 & -1.06 & 1327.1 & 0 & -2.51 & $6 / 0$ \\
\hline Terpenoid (13) & -4.08 & 0.0 & -2.50 & 100 & 1911.12 & 1.03 & -6.44 & 996.3 & 1 & -4.45 & $4.5 / 0$ \\
\hline Terpenoid (11) & -3.92 & -2.14 & -2.61 & 100 & 2029.96 & 0.81 & -4.97 & 1063.4 & 0 & -3.30 & $2.8 / 6$ \\
\hline Terpenoid (12) & -3.86 & -2.58 & -2.24 & 100 & 2568.42 & $\mathbf{0 . 7 3}$ & -4.83 & 1371.4 & 0 & -3.42 & $3.2 / 2$ \\
\hline Terpenoid (10) & -3.78 & 0.0 & -2.04 & 100 & 3810.83 & 1.15 & -5.75 & 2100.7 & 1 & -3.59 & $0.8 / 1$ \\
\hline Rosmariquinone & -3.72 & -1.53 & -2.62 & 100 & 1720.64 & 0.35 & -4.43 & 889.4 & 0 & -4.13 & $4 / 0$ \\
\hline Tanshinone & -3.62 & -1.87 & -2.21 & 100 & 1485.61 & -0.07 & -3.49 & 758.9 & 0 & -4.94 & $4.5 / 0$ \\
\hline Lycorin & -3.58 & -6.56 & -4.58 & 77.15 & 363.96 & -0.34 & -1.45 & 183.6 & 0 & -4.09 & $6.9 / 2$ \\
\hline Glycyrrhizin & -3.41 & -7.77 & -8.64 & 0 & 0.01 & $\begin{array}{l}-0.71 \\
\end{array}$ & -5.12 & 0.0 & 3 & -0.46 & $21.3 / 6$ \\
\hline Triterpenoid (14) & -2.62 & -2.99 & -3.14 & 93.89 & 268.41 & 1.41 & -7.15 & 151.8 & 1 & -1.97 & $4 / 1$ \\
\hline Betulinic acid & -2.35 & 0.0 & -2.96 & 94.63 & 296.40 & 1.36 & -6.94 & 169.0 & 1 & -1.95 & $3.7 / 2$ \\
\hline
\end{tabular}

